\title{
System of Management of Safety: Master Program of Sanitization in a Company of the Region
}

\author{
Sistema de Gestión de Inocuidad: Programa Maestro de Sanitización en una \\ Empresa de la Región
}

FORNÉS-RIVERA, René Daniel, GONZÁLEZ-VALENZUELA, Elizabeth, LÓPEZ-FIGUEROA, Julio César and GONZÁLEZ-DEL REAL, Melanie Alexandra

Instituto Tecnológico de Sonora. Avenida Antonio Caso s/n. C.P. 85000 Cd. Obregón, Sonora

ID $1^{\text {st }}$ Author: René Daniel, Fornés-Rivera / ORC ID: 0000-0002-7438-0056, Researcher ID Thomson: G-3906-2018, arXiv Author ID: rene_fornes, CVU CONACYT ID: 280435

ID $1^{\text {st }}$ Coauthor: Elizabeth, González-Valenzuela / ORC ID: 0000-0003-3774-5324, Researcher ID Thomson: G-5042-2018, arXiv Author ID: elizabeth_gonzalez, CVU CONACYT ID: 276316

ID $2^{\text {nd }}$ Coauthor: Julio César, López-Figueroa /

ID $3^{\text {rd }}$ Coauthor: Melanie Alexandra, González-Del Real /

DOI: $10.35429 / J M P C .2019 .15 .5 .1 .9$

Received March 10, 2019; Accepted June 30, 2019

\begin{abstract}
Safety is established as an essential part of the food industry because it guarantees that the products consumed are of quality and do not cause harm to health. The company studied does not have a Master Sanitation Program (PMS), an essential tool to perform health tasks in it. In order to meet the requirements established in ISO 22000: 2018, Food Safety Management System (SGIA), the company needs to have a PMS in its processes to improve its Food Safety Management System. The procedure of this investigation consisted of: identifying the main process; Sanitation processes; determine the percentage of compliance with the SGIA; determine SOPs; identify type of sanitation and frequency of cleaning of areas; establish training plan; and elaborate PMS. The main results were: determining the percentage of compliance with the SGIA through an audit through a checklist; realization of SOPs of each existing equipment in the process area; realization of an equipment cleaning matrix indicating the type of sanitization required; tabulation of plant areas including frequency of cleaning and preparation of PMS, concluding satisfactorily with the objective
\end{abstract}

Safety, Management, Sanitization

\begin{abstract}
Resumen
La inocuidad se establece como parte esencial de la industria alimenticia ya que garantiza que los productos que se consumen sean de calidad y no causen daño a la salud. La empresa estudiada no cuenta con un Programa Maestro de Sanitización (PMS), herramienta esencial para realizar tareas de sanidad en la misma. Con el propósito de cumplir requisitos establecidos en la norma ISO 22000:2018, Sistema de Gestión de Inocuidad Alimentaria (SGIA), la empresa requiere contar con un PMS en sus procesos para mejorar su Sistema de Gestión de Inocuidad en Alimentos. El procedimiento de esta investigación consistió en: identificar el proceso principal; los procesos de sanitización; determinar el porcentaje de cumplimiento del SGIA; determinar SOPs; identificar tipo de sanitización y frecuencia de limpieza de áreas; establecer plan de capacitación; y elaborar PMS. Los principales resultados fueron: determinación del porcentaje de cumplimiento con el SGIA a través de una auditoría por medio de una lista de verificación; realización de SOPs de cada equipo existente en área de proceso; realización de una matriz de limpieza de equipos indicando el tipo de sanitización necesario; tabulación de áreas de la planta incluyendo frecuencia de limpieza y elaboración de PMS, concluyendo satisfactoriamente con el objetivo.
\end{abstract}

Inocuidad, Gestión, Sanitización

Citation: FORNÉS-RIVERA, René Daniel, GONZÁLEZ-VALENZUELA, Elizabeth, LÓPEZ-FIGUEROA, Julio César and GONZÁLEZ-DEL REAL, Melanie Alexandra. System of Management of Safety: Master Program of Sanitization in a Company of the Region. Journal of Microfinance Planning and Control. 2019, 5-15: 1-9

\footnotetext{
* Correspondence to Author (email: rene.fornes@itson.edu.mx)

$\dagger$ Researcher contributing first author.
} 


\section{Introduction}

In the history of man, food has been the strongest evolutionary factor. Its progress dates back to about seven million years, during which time it underwent transformations. At first, it was based on fruits, but as the development of civilizations, it became more diverse and in addition to fruits and other vegetables, it included roots and nuts (Montaño, 2018). Globally, the snack market has a value of more than 26 billion dollars, according to Business Wire data. This is because they are used as a snack (High Level, 2018). According to Euromonitor International, Latin America has $12.1 \%$ of the global salty snack market. Growth is expected to be $6.2 \%$ from 2016 to 2021 since processed snacks have a high percentage of growth in all categories (Rioja-Scott, 2018).

Mexico registers the highest level in the world in purchases that are mainly aimed at soft drinks, cookies and the well-known "snacks or snacks". The global average of visits for the purchase of mass consumption items is 100 per year; while the Mexican makes on average 260 annual visits (FORBES, 2018).

The snack or snack sector is one of the most relevant among Mexican consumers. The study emphasizes that $62 \%$ consume them several times a week, $23 \%$ daily and only $15 \%$, once a week. There is a wide variety of snacks, which have different flavor characteristics, such as: potatoes, tortilla chips, wheat flour rinds, pork rinds, peanuts, etc. (Rioja-Scott, 2018).

Mexico continues to be one of the most important markets for ultra-processed foods since it is the country that has the highest consumption of this type of food per capita, with 214 kilos. Among what are considered ultra processed foods are sugary drinks, snacks or snacks, cereals and sweets as main categories (Stott, 2018). According to the National Institute of Statistics and Geography (INEGI), fried snacks generate a market with a total value of $\$$ 3,232 million in the country, and a production of 22,558 tons. In this area, french fries, pork rinds, etc. are concentrated. Taxes on junk food are not an obstacle to the consumption of fried potatoes in Mexico because, according to Kantar Worldpanel, in 2017, 90\% of Mexican households acquired french fries and bought them approximately 13 times a year (High Level, 2018).
Sonora is a national leader in potato production, because it is the main input for frying / snack making. Likewise, Sonora makes the assortment of the national internal market and in the same way the state market (SAGARHPA, 2018).

Food safety refers to the existence of hazards associated with food at the time of consumption, and can occur at any point in the food chain, adequate control through it is essential. Thus, food safety is ensured through the combination of efforts of all parties involved in the food chain (ISO 22000, 2018).

Ensuring and guaranteeing food safety is a necessity that is carried out worldwide. In order to meet this expectation, it is necessary to design, implement, maintain and certify the management of the productive processes of food processing along the entire production chain. The certification of certain standards demonstrates safety management within the company, allowing it to have control of the processes, manage suppliers, provide responses to buyers and guarantees to final consumers (IRAM, 2017).

Food establishments must ensure that all facilities, machinery, utensils and other equipment are properly cleaned and disinfected so that they are not a source of food contamination. Therefore, it is convenient to have a sanitization program (cleaning and disinfection) that clearly specifies the area or equipment to perform the work, the way in which it should be performed, the frequency, the products and utensils needed, the safety material and those responsible for each activity, in order to allow the removal of dirt and to control the bacterial population properly; also that the facilities and equipment are prepared for the next production cycle (Delgado and Díaz, 2006).

The company under study serves the snack market; The production manager mentions that its objective is to transform the inputs into a finished product that meet the safety and sanitation requirements for its consumption. Within the plant is the production area, seasoning, packaging, quality, laboratory, maintenance offices, administrative area, warehouse of raw material and finished product (Production Manager, 2019). 
The production area has three lines: extruded, flour and toast. In the extrudate line, the product goes through extrusion, baking, seasoning and packing processes, in the flour line, the product goes through frying, cooling, seasoning and packing processes, and finally, in the toast line, the product goes through molding, frying, cooling, seasoning and packaging processes.

The inputs are: water, electricity, equipment, instruments and tools, oil, flour, pasta, dyes, flavorings, salt, corn, specifications of quantities for mixing, production order, packing material and cleaning material. The products are a great variety of snacks, mainly fried foods, tortillas or toasts, being seasoned with different flavorings, which gives them spicy and salty flavors. Also, the product is packaged individually and in their respective boxes.

The person in charge of safety in the company, mentions that there is no Master Sanitation Program (PMS), where the cleaning of process equipment, areas, buildings and facilities with their frequency, and personnel is documented. involved, as well as chemicals, safety equipment, tools and equipment for cleaning. It is essential to comply with this program, because it is part of the Prerequisite Program (PPR) that must be implemented in the Food Safety Management System (SGIA) according to ISO 22000: 2018 (Gión, 2019). Table 1 shows the types of pathogens or contaminants that may exist in the food production process, including their description.

\begin{tabular}{|l|l|}
\hline Pollutant & \multicolumn{1}{c|}{ Description } \\
\hline Biological & $\begin{array}{l}\text { They constitute bacteria, parasites, fungi, viruses, and } \\
\text { prions, causing food poisoning. }\end{array}$ \\
\hline Physical & $\begin{array}{l}\text { Any foreign material present in a food that comes from } \\
\text { processing operations or external contamination. } \\
\text { (Presence of metals, rings, remains of packaging } \\
\text { material, plastics, glass, metals. }\end{array}$ \\
\hline Chemical & $\begin{array}{l}\text { Agents that may be present naturally in food; they may } \\
\text { be products resulting from animal or plant metabolism } \\
\text { or they may also be due to accidental contamination } \\
\text { (herbicides, pesticides, cleaning products. }\end{array}$ \\
\hline
\end{tabular}

Table 1 Biological, physical and chemical contaminants Source: Félix (2016)

The purpose of having a PMS lies in the growing concern of consumers for foods free of physical, chemical or biological pollutants that may cause harm to health, however, there are no demands or complaints of the clients.
Therefore, the company seeks to reduce these risks, ensuring the safety of its products, through this program, so that it is more practical to take care of cleaning and disinfection aspects throughout the plant, and that, at the same time, it is complying with the requirements of the SGIA. It is important to mention that the PMS has certain requirements which must be met as: cleaning and disinfection; general requirements; cleaning and disinfection agents and tools; cleaning and disinfection programs; onsite cleaning systems; and monitoring of sanitation effectiveness (Girón, 2019).

\section{Problem Statement}

Safety is the responsibility of the food industry because customers want to be sure that the products they consume are safe. Having a PMS in the company is extremely necessary because it indicates the specific tasks related to cleaning and disinfection that must be performed in plants that handle food to obtain a safe product, suitable for human consumption. The PMS will be carried out in order to comply with the requirements of the SGIA determined by the ISO 22000: 2018 standard. As described above, it is established that there is a need for a PMS in the plant, because it is part of the SGIA established by ISO 22000: 2018 and it is lacking.

\section{Objective}

Prepare a Sanitation Master Program in the processes of the company under study, through the requirements established in ISO 22000: 2018, to access a possible food safety certification.

\section{Literature review}

A management system is a tool that allows you to optimize resources, reduce costs and improve productivity by evidencing data in real time that will allow decisions to correct failures and prevent the occurrence of expenses (FAO \& WHO, 2016), cited in (Layme \& Párraga, 2019). The adequate structuring of the food hygiene health management systems is a complex system that integrates aspects such as: public policies, capacity to comply with international guidelines, epidemiological monitoring and surveillance systems, and timely and preventive management in the face of emerging risks (Tafur, 2009; Moussiaux et al., 2017), cited in (Rojas \& Barrera, 2019). 
ISO 22000 is an ISO series standard focused on food, which defines and specifies the requirements to develop and implement a Food Safety Management System (SGIA), in order to achieve international harmonization that allows an improvement in food security during the course of the entire supply chain (AVR, 2016). This standard also integrates into the SGIA, the principles of the Hazard Analysis and Critical Control Point (HACCP) system and the application stages developed by the Codex Alimentarius Commission.

Through auditable requirements, it combines the HACCP plan with Prerequisite Programs (PPR) or its equivalent term Good Manufacturing Practices (BPM), they are considered a set of guidelines established to ensure a clean and safe working environment that, at the same time, avoid food contamination at the different stages of its production, industrialization and commercialization (ISO 22000, 2018b). The ISO 22000 (2018) standard states that, the adoption of a SGIA is a strategic decision for an organization in order to improve its overall performance in food safety.

The presence of resilient systems focused on health food management is related to robust and efficient structures, aimed at ensuring products for consumers (Qekwana, McCrindle, Oguttu, \& Grace, 2017). In this sense, the systems that support food safety become a strength for the economies, and national and international markets by guaranteeing food that is fit for consumption (Kotsanopoulos \& Arvanitoyannis, 2017; McDermott \& Wyatt, 2017), cited in (Rojas \& Barrera, 2019).

The Codex Alimentarius Commission was created by the Food and Agriculture Organization of the United Nations (FAO) and the World Health Organization (WHO) in order to implement its joint program on food standards (FAO, 2018). It is a collection of food standards and related texts accepted internationally and presented in a uniform manner. The purpose of these food standards and related texts is to protect the health of the consumer and ensure the application of fair practices in the food trade. The purpose of its publication is to guide and encourage the development and establishment of definitions and requirements applicable to food to favor its harmonization and, thus, facilitate international trade (ANUAA, 2018).
At the international level, the role of the Codex Alimentarius Commission as a coordinator of food standards and as a technical reference of the World Trade Organization (WTO) has been strengthened, incorporating and developing safety criteria strengthening international trade Martín (2003), cited in (Navarro \& Zúñiga, 2019).

A PMS includes the cleaning of the equipment, tools, containers, facilities, and identifies the area or equipment to be cleaned, the period of time between each cleaning and the person responsible for performing the task. To create a PMS, cleaning frequencies must be defined as tasks. When they first develop, the appropriate frequencies may not be known. In these cases, an estimate must be made, which can then be adjusted more or less frequently using the results of the environmental monitoring and integrated pest management programs to validate the frequencies (Food Partners, 2017).

The importance of this program in food establishments is highlighted as it prevents their contamination by surfaces that contact them directly. Likewise, it is indicated in these works that to guarantee good hygienic / sanitary behavior in food establishments it is essential that material conditions exist to facilitate cleaning and disinfection activities (Guzmán and Arteaga, 2017).

\section{Methodology}

The object of study was the entire plant; The support materials were: a) ISO 22000: 2018 SGIA Standard. This rule specifies the PPRs to comply with the SGIA, which was used as a guide for the procedure; b) ISO / TS 22002: 2009 Standard Technical Specification of PPRs for cleaning and disinfection; It was used as support to develop the PMS; c) ISO / TR 10013: 2001: Guidelines for the documentation of the Quality Management System (QMS). This standard was used as a guide to obtain the steps for the development and maintenance of the necessary documentation to ensure a QMS; d) Format for writing the PMS, granted by the Document Control area of the company under study; and e) NOM-251-SSA1-2009 hygiene practices for the food, beverage or food supplement process, used as a reference when performing the Standardized Sanitation Operating Procedures (SOPs). 
Below is the procedure required to fulfill the objective, developing the PMS in accordance with ISO 22000: 2018.

1. Identify the main process. In order to know the production process, a tour of the plant was carried out by throwing a descriptive argument through a SIPOC.

2. Identify sanitation processes. The surfaces and equipment to be sanitized were identified by means of a route, where the production lines are described, including the equipment, the number of operators, responsible personnel and flowcharts for the equipment.

3 Determine percentage of compliance with the SGIA. A checklist was designed based on the ISO 22000: 2018 standard, which was used to conduct an audit of the SGIA, in order to review the requirements of the standard and obtain the current compliance percentage. With this information it was determined which requirements are related to the PMS and a graphic representation of the results was elaborated to visualize the sections that present major deficiencies.

4. Determine SOPs. Sanitation processes were written in documents that describe (through instructions or steps) the sequence of operations that should be followed in the process. ISO / TR 10013: 2001 was taken as a reference and the purpose, scope, definitions, those responsible, the description of the procedure, the required formats, references and annexes were established. Also, NOM-251SSA1-2009 was considered when capturing the procedures, considering criteria established by the standard.

\section{Identify type of sanitation and} frequency of cleaning of areas. Through the route previously made, the production lines that the plant has, and through a talk with the general manager and quality analyst, the names of the products (not mentioned), as well as the limitations or allergens ( will not be mentioned) with which each product has. All this was reflected in a cleaning matrix, which indicates the type of cleaning that should be performed on the equipment, depending on the product that started and ended in production. Since each product has certain types of limitations and some of them could be allergenic, therefore the type of cleaning would depend on this.
To achieve this, it was necessary to use conditional formulas in an xls format. The frequency of cleaning of all the most general areas of the company under study was determined, as well as that of the equipment in the process, including these, and the ideal duration of the activity. All with information provided by cleaning managers and sanitation operators. These data were tabulated and classified according to the corresponding area.

6. Develop support material for training. In relation to the sanitation processes for the company's employees, especially for the 45 operators and three production supervisors, support material was developed with the purpose of training them in the identification of risks and dangers that may cause damage to their health or that affect the safety of the product and how to prevent them, the pollutants that may occur, the proper use of cleaning utensils and safety equipment for personnel performing sanitation tasks.

\section{Prepare Master Sanitation}

Program. The PMS document was written, so that the company's general activities were included in terms of sanitizing them, indicating their frequency, cleaning method and those responsible for carrying it out. In addition, ISO / TR 10013 was taken as a reference to establish the purpose, scope, definitions, those responsible, the description of the procedure, the required formats, references and annex. In the description section, the tables were added with the frequency corresponding to each equipment, surface or utensil, the SOPs, the cleaning matrix and the training plan.

\section{Results}

Below is what you get when developing the procedure.

1. Identification of the main process. With the information collected from the route of the production process that includes the four production lines that are managed in the plant, a description is made of it:

Suppliers: the suppliers of the processes are, warehouse of raw material that is where it is maintained and management who provides information. 
Inputs: As inputs to the process, there is a raw material which is flour, flavoring, coloring, oil, water, salt and peanuts. In addition, the recipe of each product as it indicates specific quantities and finally, a production plan.

Process: Where the 4 existing production lines in the plant are observed, which are Toasted, Mix, Extruded and Flour, indicating the process through which each product that is made in each line passes.

Output: In which is packed product that is the one that is addressed directly to the customer. Product for reprocessing, that there could be some defect in the wrapper, however, the product did meet the standard, so it is packed again. Non-compliant product, which did not meet the standard. Merma, which is a product that is discarded. Production registration and non-compliant product registration, files with information obtained from what was explained above.

Customers: Warehouse of finished product, where the product is stored in boxes for distribution. Waste deposit, dedicated to locate the product to be discarded. Production supervisor and production manager who will obtain the records mentioned above.

\section{Identification of sanitation} processes. The processes have production lines which are tortilla, mix, flour and extruded with the areas of process, seasoning and packaging, with the cleaning procedure that must be followed for the proper sanitization of the equipment. In total, 13 diagrams resulted, of which two (Kneader and Dough Feeder) belong specifically to the tortilla line, (Bands, fryer, oven, seasoning cylinder) can belong to two or more lines and were embodied in a single diagram because they have The same procedure. The remaining ones (floors, Hawaiian curtains and walls) correspond to the sanitation department. Due to their space and size, the flowcharts and the layout of the process are not shown.

3. Determination of the percentage of compliance with the SGIA. The result of the audit in the SGIA was $61 \%$. The percentage of compliance with each clause can be seen in Graph 1.

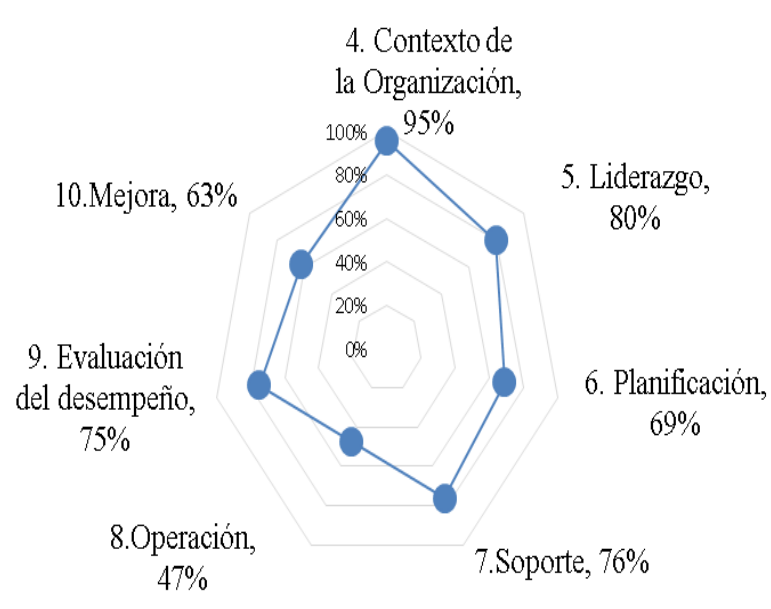

Graphic 1 Percentage of compliance with each clause of ISO 22000: 2018

Having obtained the previous results, it was determined that clause 8 presents a greater opportunity for improvement, due to the lower percentage of compliance, see Graphic 2.

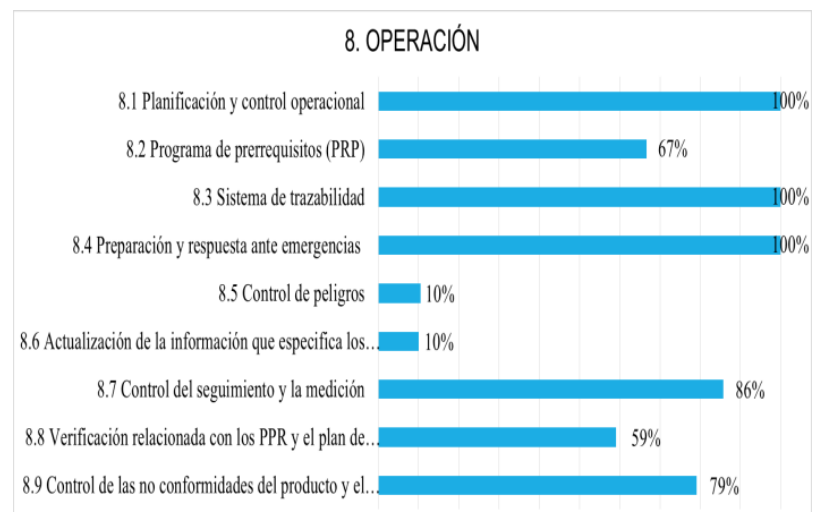

$0 \% 10 \%$ 20\% 30\% 40\% 50\% 60\% 70\% 80\% 90\% 100\%

Graphic 2 Percentage of compliance with clause 8 of ISO 22000: 2018

As can be seen, the SGIA has opportunities for improvement, especially in clause 8 , however, the company is in the process of meeting requirement 8.5 and its derivatives when implementing the HACCP plan, but for this it is necessary to meet requirement 8.2 to comply with the PPR established in the standard and then attend to its derivatives once the PMS is implemented.

4. Determination of SOPs. Each SOPs is a format with a series of tables (for space and size will not be displayed) which are composed of: name; purpose; scope; definitions; responsibilities; description; required forms; references; change history, annexes; frequency; and flow chart. 
Each team and areas had a PCOS developed, which are: a) kneader; b) conveyor belts; c) mass feeder; d) seasoning cylinder; e) fryer; f) humidifier; g) extruders; h) oven; and i) packing machine In addition to areas such as: a) floor cleaning; b) cleaning of Hawaiian curtains; c) toast line cleaning; and d) mix line cleaning; The above is carried out as a procedure for the sanitization of each equipment which was established in documents that indicate the specific tasks related to the cleaning that must be performed on the equipment to obtain an innocuous product..

\section{Identification of type of sanitation} and frequency of cleaning of areas. In the cleaning matrix, see Table 2, the production lines and the products that are produced corresponding to their line or if they are only packaging products without modification are shown. It is noted that this includes the type of run (if it ends or starts) and the limitations. This works with respect to the product that starts and ends and this depends on the allergen or limiting material it contains. Based on this and with the help of conditionals, it is possible to determine the type of cleaning, whether it is deep or dry.

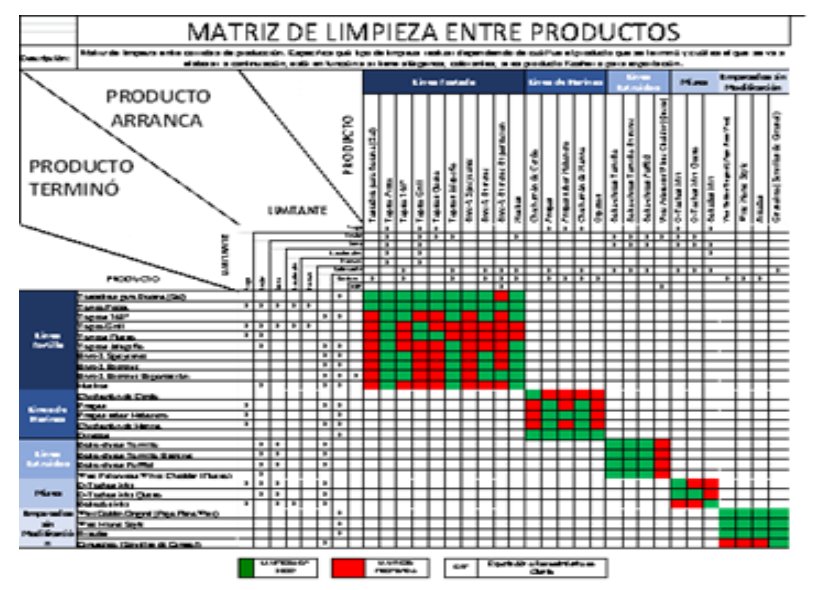

Table 2 Matrix of Cleaning in production lines

In the cleaning tables of areas each area of the company is indicated in general, establishing the frequency of cleaning of the same, being these: exteriors, offices, parking lots, toilets, warehouses, production offices, engineering and similarly, of the process teams, including the duration of each activity (per space will not be shown).

\section{Development of support material for} training. In order that the managers can use this material to train and adapt the personnel involved for the responsible execution of the tasks specified in the PMS, this material was prepared considering the following: a) identification of risks in the handling of chemical substances; b) cross contamination: color coding; c) safety hazard identification: biological, physical and chemical contaminants; d) safety equipment: Personal Protective Equipment; e) risk prevention; f) hazards: Good Manufacturing Practices; and g) recommendations.

\section{Preparation of Master Sanitation} Program. All previously made products (process description, equipment tables and frequency of cleaning areas, cleaning matrix of production lines, support material for training) were taken and placed in their corresponding section making use of ISO T / R 10013, and the document control format established by the company and the section procedures are described in each of the tabulations of the frequency of cleaning of areas and equipment, followed by the cleaning matrix and the training support material (because it is a large document, the PMS is not shown).

\section{Conclusions}

It is concluded that the objective of the project was met, when carrying out a Sanitation Master Program at the proposed level for a possible certification, because the requirements of ISO 22000: 2018 were reviewed, and clause 8 . Special attention was given to PMS. of products that comprise it, as well as frequency tables for cleaning areas, cleaning matrix in production lines, training plan, process lay-out and SOPs, which are extremely necessary for those responsible for the activities of sanitation execute their activities properly.

It is important to mention that it was possible to know the current compliance status of the company in terms of ISO 22000: 2018, since knowing it, it can take relevant actions and address the critical points or areas of opportunity and thus raise the percentage of compliance. 
The importance of complying with this program is essential for food business, since it provides the necessary documentation of the guidelines and procedures that must be carried out to carry out the cleaning and disinfection activities of equipment, areas, facilities , etc., where the product is handled, so that it is safe and of the highest quality.

\section{Recommendations}

During the development of the project it was observed that the cleaning procedures were not performed as they should. This was due to the lack of the necessary documentation to facilitate this task to the operator. That is why it is recommended that those responsible for carrying out the activities have access to these documents and thus avoid any type of failure. It is also recommended to train those responsible for carrying out sanitation activities monthly.

Finally, it is worth mentioning that it is very important that the company meets the requirements of the ISO 22000: 2018 standard, making use of its most recent version and that it applies continuous improvement throughout the SGIA to be in possibilities at the moment of wanting to access a possible certification.

\section{References}

Alto Nivel. (2018). Alto Nivel. Obtenido el 12 de Marzo de 2019 de https://www.altonivel.com.mx/estilo-devida/gastronomia/papas-fritas-botana/

ANUAA. (2018). Codex Alimentaius. Quinta Edición. Obtenido el 20 de Septiembre de 2019 de

http://www.fao.org/3/CA1176Es/ca1176es.pdf

AVR. (2016). Certificación ISO 22000:2005. Obtenido el 10 de febrero 2019 de http://www.avr.com.mx/AVR/ISO_22000_files /Ficha\%20Certificacion\%20ISO\%2022000.pdf

Delgado, E., y Díaz, P. (2006). Elaboración y documentación de un programa de limpieza y desinfección de los laboratorios del departamento de microbiológia de la Pontificia Universidad Javeriana. Bogotá. Recuperado el 13 de mayo del 2019; de: https://www.javeriana.edu.co/biblos/tesis/cienci as/tesis281.pdf
FAO. (2018). El Codex y los consumidores. Obtenido el 15 de mayo de 2019 de http://www.fao.org/3/y7867s/y7867s07.htm

Félix, M. (2016). Peligros físicos, químicos y biológicos; la estrategia 'anti-error' en las cocinas. Obtenido el 12 de abril de 2019 de Restauración Colectiva: https://www.restauracioncolectiva.com/n/peligr os-fisicos-quimicos-y-biologicos-la-estrategiaanti-error-en-las-cocinas

FORBES. (2018). Mexicanos, de los mayores consumidores de botanas en el mundo. FORBES. Recuperado el 24 de Mayo de 2019, de: https://www.forbes.com.mx/mexicanos-delos-mayores-consumidores-de-botanas-en-elmundo/;

Food Partners. (2017).Qué es importante en un Programa Maestro de Limpieza y Sanitización? Obtenido el 14 de Marzo de 2019; de Food Partners:

http://www.foodpartnerslatam.com/que-esimportante-en-un-programa-maestro-delimpieza-y-sanitizacion/

Gerente de Producción. (2019). Información de Producción. (G. Luna, y M. González, Entrevistadores).

Girón, H. (2019). Información de Producción. (G. Luna, y M. González, Entrevistadores).

Guzmán, E., y Arteaga, K. (2017). Programa de limpieza y sanitización para la industria de jugos de fruta Elikath. Obtenido el 22 de abril de 2019 de

https://es.scribd.com/presentation/353414323/P rograma-de-Limpieza-y-Sanitizacion-ParaIndustria-de-Jugos-de-Fruta-Elikath

IRAM. (2017). Sistemas de gestión de la inocuidad de alimentos. Obtenido el 22 de mayo de 2019 de: http://aplicaciones.iram.org.ar/userfiles/folletos/ Certificacion_de_los_Sistemas_idad_Alimentar ia_22000.pdf 
Layme, P., Eugenia, M., \& Párraga, B. (2019). Diseño de un Sistema de Análisis de Peligros y Puntos Críticos de Control "HACCP" para la Línea de Laminado de Quinua en la Planta Pura Pura de la Empresa "Sociedad Industrial Molinera SA(Doctoral dissertation). Documento recuperado el 15 de agosto de 2019, de: https://repositorio.umsa.bo/bitstream/handle/12 3456789/20795/TES-

1114.pdf? sequence $=1$ \&is Allowed $=\mathrm{y}$

Navarro, Y. G., \& Zúñiga, L. P. (2019). Desarrollo de una herramienta para evaluar los programas prerrequisitos del Sistema (HACCP), instaurado en la planta de beneficio de miel de abejas de la UEB Apícola de Sancti Spíritus. InfoCiencia, 19(2), 57-67. Documento recuperado el 16 de agosto de 2019, de: http://www.infocienciass.cu/index.php/infocien cia/article/view/242/389

ISO 22000. (2018). Food safety management systems - requirements for any organization in the food chain. Obtenido el 10 de febrero de 2019, de International Organization for Standardization:

https://www.iso.org/obp/ui/es/\#iso:std:iso:2200 0:ed-2:v1:en

ISO 22000. (2018b). International Organization for standardization. Recuperado el 12 de mayo 2019, de https://www.iso.org/iso-22000-foodsafety-management.html

Rojas, A. C., \& Barrera, A. P. (2019). Análisis de validez y reproducibilidad de un instrumento para sistemas nacionales de inocuidad de alimentos. Revista científica ecociencia, 6(3). Documento recuperado el 15 de agosto de 2019 de

https://search.proquest.com/openview/c8d1411 e148006c7bd317c4e9a00b47d/1?cbl=2043236 \&pq-origsite $=$ gscholar

Rioja-Scott, I. (2018). Informe anual de snacks y panificación 2018. Industria Alimenticia. Recuperado el 22 de Abril de 2019; de: https://www.industriaalimenticia.com/articles/8 9491-informe-anual-de-snacks-y-panificacion2018

Stott, I. (2018). Industria Alimenticia. Recuperado el 14 de Febrero de 2019, de https://www.industriaalimenticia.com/articles/8 9355-informe-anual-de-m\%C3\%A9xico-2018
SAGARPA. (2018). Guía básica para la elaboración de un plan de análisis de peligros y puntos críticos de control para un establecimiento TIF. Recuperado el 10 de julio de 2019 , de:https://www.gob.mx/senasica/documentos/g uia-basica-para-la-elaboracion-de-un-plan-deanalisis-de-peligros-y-puntos-criticos-decontrol-para-establecimientos-tif-plan-haccp 